\title{
Pembinaan Keagamaan dalam Meningkatkan Religiositas Narapidana dan Implikasinya dalam Bimbingan dan Konseling
}

\author{
Said Ikhwani ${ }^{1}$, Muhammad Nasir ${ }^{2} \&$ Marimbun $^{3}$ \\ ${ }^{123}$ Bimbingan dan Konseling Islam, IAIN Langsa, \\ marimbun.kauman@gmail.com
}

\begin{tabular}{c|cc} 
First received: & Revised: & Final Accepted: \\
01 January 2021 & 02 February 2021 & 04 March 2021
\end{tabular}

\begin{abstract}
The purpose of this research is religious development in increasing religiosity, how to respond to descriptions and how the results of religious development activities are. Qualitative research method with a descriptive approach. The research subjects were prisoners, Ustadz, and correctional officers. Data collection techniques are observation and interviews. Data analysis through data reduction, data presentation, and drawing conclusions. The results of the study indicate that urgent religious development is held in correctional institutions in collaboration with several institutions such as the Islamic Shari'ah Service, the Syari'ah Court, the Indonesian Da'i Association, the Ulema Consultative Council, and the Darul Mukhlisin Islamic Boarding School in Aceh Tamiang. The results of this collaboration confirmed the Al-Hikmah Islamic Boarding School in the Correctional Institution. The existence of the Al-Hikmah Islamic Boarding School helps religious development in the form of congregational prayers, dhikr, prayer, reading the Koran, cults, and studying books, and conducting religious studies filled by several ustadz from outside the prison. The response to religious development activities was initially very refusal, but gradually the people realized the benefits of these activities. The religious guidance carried out has an effect on increasing the religiosity of the inmates so that religious behavior can be seen in various religious activities.
\end{abstract}

Keywords: Religious Development, Religiosity, Prisoners

\begin{abstract}
Abstrak
Tujuan penelitian ini mendeskripsikan pembinaan keagamaan dalam meningkatkan religiositas, bagaimana respon narapidana serta bagaimana hasil kegiatan pembinaan keagamaan. Metode penelitian digunakan kualitatif dengan pendekatan deskriptif. Subjek penelitian adalah Narapidana, Ustadz, dan Petugas Lembaga pemasyarakatan. Teknik pengumpulan data adalah observasi dan wawancara. Analisis data melalui reduksi data, penyajian data, dan penarikan kesimpulan. Hasil penelitian bahwa pembinaan keagamaan urgen diadakan di lembaga pemasyarakatan bekerja sama dengan beberapa lembaga seperti Dinas Syari'at Islam, Mahkamah Syari'ah, Ikatan Da'i Indonesia, Majelis permusyawaratan Ulama, serta pesantren Darul Mukhlisin yang berada di Aceh Tamiang. Hasil kerja sama tersebut mengukuhkan pesantren AlHikmah di Lembaga Pemasyarakatan. Keberadaan pesantren Al- Hikmah membantu pembinaan keagamaan berupa shalat berjamaah, dzikir, bershalawat, membaca Alquran, kultum, serta belajar kitab dan mengadakan kajian keagamaan yang diisi oleh beberapa ustadz dari luar Lapas. Respon narapidana terhadap kegiatan pembinaan keagamaan pada awalnya sangat menolak, Namun secara perlahan para narapidana menyadari manfaat kegiatan tersebut. Pembinaan keagamaan yang dilakukan
\end{abstract}


memberikan efek terhadap peningkatan religiositas warga binaan sehingga perilakuperilaku religius narapidana terlihat dengan berbagai kegiatan keagamaan.

Kata Kunci: Pembinaan Keagamaan, Religiositas, Narapidana

\section{PENDAHULUAN}

Lembaga Pemasyarakatan (LAPAS) sebagai salah satu institusi penegak hukum, merupakan muara dari peradilan pidana yang menjatuhkan pidana penjara kepada para terpidana (Purwasari, 2013; DM, 2017; Damayanti, 2011). Pelaksanaan hukuman penjara bagi narapidana tidak dilakukan semata-mata sebagai sebuah upaya balas dendam dan menjauhkan narapidana dari masyarakat (DM, 2017; Gamis, 2016; Dhiniyati, 2019). Penjara merupakan bentuk pengisolasian diri dari tembok penjara ternyata memberikan pengaruh terhadap psikis narapidana yang menjalani masa tahanan. Tidak dipungkiri bahwa narapidana yang berada di lembaga pemasyarakatan merupakan orang yang melakukan tindakan yang melanggar hukum. Munculnya dorongan untuk melakukan tindakan kejahatan pada diri narapidana merupakan bentuk dari dampak kurangnya pengendalian diri pada narapidana. Hal tersebut bisa disebabkan karena jauhnya diri narapidana terhadap fitrahnya (Nurhuda, 2020; Dhiniyati, 2019)

Fenomena yang terjadi di era modern seperti korupsi, penganiayaan, pencurian, mengkonsumsi NAPZA, dan sebagainya, merupakan perilaku atau perbuatan yang memberikan dampak buruk kepada orang lain. Perbuatan-perbuatan tersebut merupakan bentuk dari perbuatan dzhalim, yang dimana seseorang sudah tidak lagi menempatkan sesuatu pada tempatnya, sebagai contoh yaitu seorang koruptor yang dimana ia telah keluar dari fitrah keadilan nya (Saryono, 2016). Gejala tersebut menjelaskan bahwa banyak manusia yang belum mengikuti fitrahnya, sementara fitrah menjadi jalan dalam mendekatkan diri kepada Allah Swt sebagai jati diri manusia (Saryono, 2016)

Manusia memiliki kemampuan memahami kebenaran yang terpancar dari ciptaan-Nya. Kemampuan yang dimiliki manusia merupakan kemampuan akalnya. Oleh karena itu, manusia dikenal sebagai animal rationale yaitu binatang yang berpikir (Saryono, 2016; Aziza, 2018). Manusia berusaha untuk memahami realitas hidup, memahami diri serta segala sesuatu di sekitarnya melalui akhlaknya (Andriyani, 2015; Saryono, 2016). Manusia membutuhkan yang bisa memberi bimbingan menuju jalan kebajikan serta menjauhkan dari kejahatan. Petunjuk yang dimaksud ialah ajaran yang dibawa oleh Rasulullah, baik berupa kitab suci Al-quran maupun Hadis (Iryani, 2017). Tujuan Allah mengutus para rasul kepada hamba-Nya adalah membimbing mereka dalam mencapai kebahagian di dunia dan akhirat (Sutoyo, 2013). Menarik maksud dan tujuan dari diutusnya seorang rasul, dapat dipahami bersama bahwasannya manusia membutuhkan bimbingan yang mengarahkan dirinya kepada jalan yang lebih baik (Ridwan, 2018). Begitu juga yang dialami oleh para narapidana dan tahanan yang ada di Lembaga Pemasyarakatan, mereka yang telah melakukan tindakan buruk tentunya harus diberikan berbagai bimbingan, arahan, maupun perhatian khusus. Hal tersebut dimaksudkan agar mereka dapat kembali menjadi insan yang lebih baik.

Narapidana yang menjalani masa tahanan merasa rendahnya harga diri dan 
membutuhkan pengakuan dan reward dari orang lain. Hal ini sesuai dengan pernyataan Jalaluddin (2009) mengenai faktor yang mempengaruhi atraksi interpersonal ialah salah satunya isolasi sosial. Bagi seorang narapidana kehadiran orang lain dapat memberikan kebahagiaan. Begitu juga kehadiran uztadz atau guru yang memberikan pembinaan, tentunya memberikan reward dan ketenangan bagi diri narapidana. Dapat dipahami bahwa narapidana yang berada di LAPAS sangat merasa rendah diri dan tertekan. Keadaan tersebut tentunya membuat psikologis narapidana terganggu dan menghambat perubahan perilaku narapidana untuk menjadi lebih baik. Dari permasalahan ini dipahami bahwa perlu adanya pembinaan yang dilakukan secara khusus terhadap narapidana dan tahanan agar terbentuk psikis yang sehat.

Pembinaan merpakan usaha dalam membimbing dan mengarahkan kepada tujuan tertentu (Juliana, 2015; Rahmawati, 2016). Bimbingan merupakan kegiatan dalam memberikan bantuan kepada seseorang secara berkesinambungan, agar seseorang tersebut memahami dirinya sehingga mampu mengarahkan dirinya untuk bertindak secara wajar yang sesuai dengan tuntunan dan tidak melanggar norma di lingkungan, keluarga, dan masyarakat (Mulyani, 2018; Rahim, 2021; Nurhapidoh, 2019; Nisa, 2019; Nursakilah, 2019). Oleh karena itu, seseorang dapat mendapatkan kebahagian dan memberikan kontribusi yang berarti bagi kehidupan masyarakat. Bimbingan akan membantu seseorang untuk memperoleh perkembangan secara optimal sebagai makhluk sosial (Amin, 2010).

Fenomena di Lembaga Pemasyarakatan Kelas II B Kualasimpang, bahwa narapidana memiliki tekanan emosi

dan psikis yang perlu mendapatkan perhatian. Narapidana terdiri dari kasus yang berbeda yang memiliki motivasi rendah dikarenakan kurangnya perhatihan dan dukungan dari keluarga dan orang terdekatnya. Motivasi diri narapidana sangatlah penting untuk dikembangkan dalam memberikan perubahan ke arah yang lebih baik. Program pihak pegawai LAPAS untuk memberdayakan dan membangkitkan semangat diri narapidana diantaranya kegiatan pengembangan pribadi di bidang seni, budidaya, kerajinan, maupun keterampilan las dan otomotif. Selanjutnya kegiatan pembinaan keagamaan yang diadakan di pesantren Al-Hikmah LAPAS Kelas II B Kualasimpang. Beberapa hasil penelitian terdahulu terkait religiositas nara pidana seperti hasil penelitian Febriani (2020), melihat bagaimana gambaran religiositas nara pidana berdasarkan jenis kelamin dan usia. Inayah (2020) terkait pelaksanaan bimbingan rohani untuk meningkatkan religiositas narapidana. Islamiyah (2020) mendeskripsikan model pembinaan agama Islam, faktor pendukung dan penghambat dan implikasi pembinaan agama Islam.

Penelitian ini memfokuskan kepada pembinaan keagamaan terhadap narapidana dengan tujuan mendeskripsikan pembinaan keagamaan, bagaimana respon narapidana serta bagaimana hasil kegiatan pembinaan keagamaan yang sudah dilakukan. Program pembinaan keagamaan merupakan salah satu upaya utama untuk memperbaiki akhlak narapidana agar kembali kepada fitrahnya. Pembinaan keagamaan dilakukan secara rutin agar terjaga pribadinya menjadi lebih baik.

\section{METODE}


Metode penelitian ini adalah kualitatif dengan pendekatan deskriptif. Subjek penelitian adalah Narapidana, Ustadz, dan Petugas Lembaga pemasyarakatan Kelas II B Kualasimpang. Teknik pengumpulan data yang digunakan untuk memperoleh data adalah observasi dan wawancara.

\section{HASIL TEMUAN}

Hasil temuan penelitian ini mendeskripsikan sebagai berikut:

\section{Pembinaan Pengamalan Agama Narapidana}

Pembinaan keagamaan merupakan hal yang paling urgen keberadaannya di Lembaga Pemasyarakatan Kelas II B Kualasimpang. Melalui pembinaan keagamaan diharapkan mampu memberikan perubahan perilaku bagi warga binaan ke arah yang baik. Sebagaimana informasi yang disampaikan oleh Bapak Miswan pegawai LAPAS yaitu: "Tujuan inti adanya lembaga pemasyarakatan inikan adalah pembinaan. Selain pembinaan keagamaan ada juga pembinaan karir, kita bina mereka melalui keahliannya. Kita ajarkan mereka keahlian seperti keahlian mengelas, bengkel otomotif, budidaya jangkrik, budidaya ikan, dan banyak lagi. Untuk warga binaan wanita juga ada menjahit (Wawancara/ 5 Maret 2020)

Melalui pembinaan keagamaan, diharapkan warga binaan Lembaga Pemasyarakatan Kelas II B Kualasimpang muncul kesadaran untuk memperbaiki kesalahan dan menyesali akan perbuatan telah mereka lakukan. Pembinaan keagamaan yang diadakan di Lembaga Pemayarakatan Kelas II B Kualasimpang sama perannya seperti dakwah. Mengajak, membimbing, dan mengarahkan manusia kepada jalan yang benar. Bentuk kegiatan yang dilakukan berupa kegiatan ceramah
Adapun analisis data yang digunakan pada penelitian ini adalah reduksi data, penyajian data, dan pengambilan kesimpulan.

atau penyampaian kajian keislaman yang disampaikan oleh mubaligh atau ustadz baik dari dalam LAPAS maupun dari luar LAPAS.

Pembinaan keagamaan di Lembaga Pemasyarakatan Kelas II B Kualasimpang diadakan secara terstruktur dan dibawah naungan pesantren Al Hikmah Lembaga Pemasyarakatan Kelas II B Kualasimpang yang bekerja sama dengan Mahkamah Syari'ah Aceh Tamiang, Kementrian Agama Aceh Tamiang, Majelis Permusyarawatan Ulama Aceh Tamiang, Ikatan Da'i Indonesia, serta pondok pesantren Darul Mukhlisin Aceh Tamiang. Adanya kerja sama menjadikan kegiatan pembinaan keagamaan lebih efektif dan bersinergi dengan mendatangkan berbagai da'i atau ustadz-ustadz yang berintegritas dan berwawasan keislaman. Sebagaimana informasi yang didapatkan dari Bapak Miswan pegawai LAPAS sebagai berikut: "Bentuk pembinaan yang dilakukan di lembaga ini khususnya pembinaan keagamaan seperti mengadakan pengajian. Kita undang ustadzustadz luar, ada yang dari IKADI, Dinas Syariat Islam Aceh Tamiang, Kemenag Aceh Tamiang, MPU Aceh Tamiang, guru-guru atau ustadz dari pesantren Darul Mukhlisin Aceh Tamiang, dan ada juga ustadz-ustadz jamaah tabligh lainnya. (Wawancara/5 Maret 2020)

Dari informasi yang disampaikan oleh pegawai Lembaga Pemasyarakatan Kelas II B Kualasimpang jelas diketahui bahwa mendatangkankan pemateri atau ustadz 
yang memberikan kajian keislaman dimaksudkan agar suasana pengajian atau kegiatan pembinaan keagamaan tidak membosankan. Selain dalam bentuk pengajian rutin, pembinaan keagamaan juga dilakukan dalam bentuk kelompokkelompok, setelah shalat dzuhur mereka melanjutkan kegiatan mereka dengan kultum, dzikir, dan membaca Alquran. Hal ini sesuai dengan informasi yang didapatkan dari Bapak Joni salah seorang warga binaan: "Jika tidak ada Tengku masuk kami biasanya melanjutkan dengan kultum, seperti membacakan sebuah hadis beserta arti dan penjelasan, Hal itu dilakukan secara bergantian orang yang membacanya setiap setelah shalat. Lalu kami berdzikir seperti dzikir biasanya. Setelah shalat magrib biasanya kami membaca Alquran secara berjama'ah (Wawancara/ 10 Maret 2020).

Pemilihan tema bahasan dan materi dalam pembinaan keagamaan pada umumnya ditentukan oleh ustadz atau da'i yang bersangkutan yang memberikan kajian-kajian keislaman. Adapun materi yang dibahas seputar kajian mengenai Fiqih, Akidah dan Akhlak. Setiap da'i atau ustadz yang mengisi pengajian menyampaikan tema pengajian yang berbeda. Ada kalanya mereka diberikan pengajian kitab kuning yang pada umumnya dipelajari di Dayah-Dayah. Hal ini sesuai dengan informasi dari Bapak Swidianto seorang informan yang merupakan warga binaan, bahwasanya: "Selama kami mengikuti pembinaan keagamaan materi yang kami dapati dari tengku-tengku seperti materi tentang fiqih, taharah, shalat, puasa. Dan materi-materi tentang akhlak dsb. Dan saya rasa ya tidak jauh beda dengan belajar di dayah-dayah di luar sana" (Wawancara/ 7 Maret 2020)

Kegiatan-kegiatan pengajian yang diisi lagsung oleh da'i-da'i luar tidak dilakukan setiap harinya. Pengajian tersebut diadakan setiap dua kali per minggu yaitu hari selasa dan kamis. Namun selain itu, kegiatan yang rutin dilakukan setiap harinya ialah kegiatan berupa dzikir, membaca Alquran, dan kultum setelah shalat. Kegiatan ini bersifat mandiri dan langsung diimami oleh warga binaan yang sudah ditunjuk sebagai imam di Lembaga Pemasyarakatan kelas II B Kualasimpang.

Mengenai materi khusus yang memberikan pengaruh terhadap peningkatan religiusitas narapidana sebenarnya tidak terlalu di khususkan. Semua materi memiliki efek terhadap peningkatan religiusitas narapidana. Namun, dari informasi yang didapatkan dari Bapak Miswan sebagai berikut: "Materi yang mungkin bagus untuk meningkatkan religiusitas atau spiritual narapidana ialah materi yang berkaitan dengan ibadah atau tauhid. Karena saya rasa dengan memberikan pemahaman mengenai tauhid mereka akan sadar peran utama manusia sesungguhnya saat Allah ciptakan. (Wawancara/ 5 Maret 2020)

Materi-materi pembinaan keagamaan dari informasi yang didapat pada dasarnya mempunyai efek yang sama terhadap peningkatan religiusitas narapidana. Namun ada nilai lebihnya bila materi yang diberikan mengenai ibadah dan tauhid. Materi tersebut secara langsung memberikan pemahaman tantang ke esaan Allah swt sebagai sang pencipta dan kewajiban kita untuk beribadah. Religiositas merpakan segala perilaku yang memuat nilai-nilai keagamaan. Sementara perilaku tersebut muncul karena adanya pemahaman secara langsung mengenai hakikatnya ibadah dan tauhid. Oleh karena itu, ada kelebihan tersendiri bagi peningkatan religiusitas narapidana dari materi yang diberikan. 
Selain itu, informasi yang didapatkan dari ustadz Sariyadi yang mengisi pengajian di Lembaga Pemasyarakatan ialah sebagai berikut: "Religiositas ini menyangkut dengan keimanan. Kalau untuk meningkatkan keimanan saya rasa semua kajian-kajian keagamaan sama. Karena semua apa yang diajarkan itu bertujuan untuk menambah ilmu dan kedekatan dengan Allah swt. Tinggal lagi kemauan hati untuk mendalami kajian secara sungguh-sungguh. Materi yang saya berikan mengikuti kitab kuning yang biasanya dipelajari di dayah. Yang dimana materi yang dibahas di dalamnya mencakup pembahasan mengenai Fiqih, baik tetang shalat, puasa, taharah, dan lain sebagainya. Biasanya saya mengisi pengajian sekitar satu jam hingga satu setengah jam yang dimulai dari ba'da Dzuhur. (Wawancara/ 5 Maret 2020)

$$
\text { Warga binaan Lembaga }
$$

Pemasyarakatan Kelas II B Kualasimpang sebagai penerima materi pembinaan keagamaan merasakan bahwa materi pembinaan keagamaan yang diberikan sama-sama mempunyai tujuan untuk menambah pemahaman keagamaan dan kemudian untuk menambah kedekatan dengan sang Pencipta. Sebagaimana informasi yang didapatkan dari Bapak Swidianto sebagai berikut: "Tentunya materi yang saya dapatkan berguna untuk saya. Semua materi tentunya akan memberikan kita pemahaman mengenai Islam. Jadi bila pemahaman kita tumbuh pasti kedekatan kita terhadap Islam semakin besar. Dengan adanya kegiatan keagamaan disini seperti pengajian saya banyak menjadi tahu berbagai hukumhukum syariat yang dulu saya tidak tahu. Disini Alhamdulillah saya merasa lebih baik" (Wawancara/ 7 Maret 2020). Religiositas narapidana secara efektif dapat ditingkatkan dengan menerapkan kegiatan-kegiatan pembinaan keagamaan. Pengkondisian lingkungan dengaan menanamkan nilai-nilai keagamaan dapat membentuk perilaku atau karakter religius pula.

\section{Respon Narapidana Terhadap Pembinaan Keagamaan di LAPAS Kelas II B Kualasimpang}

Munculnya kesadaran pada diri narapidana di Lembaga Pemasyarakatan Kelas II B Kualasimpang tidak dilalui dengan proses singkat. Pembinaan keagamaan diberikan secara terusmenerus, meskipun banyak diantara warga binaan yang masi merasa terpaksa mengikuti pembinaan keagamaan yang dilakukan, tidak sedikit pula dari mereka yang telah berhasil menyesuaikan diri untuk mengikuti pembinaan keagamaan secara mendalam dan serius. Banyak dari kalangan warga binaan Lembaga Pemasyarakatan Kelas II B Kualasimpang yang telah mampu menghafal beberapa ayat suci Alquran selama menjalani masa hukuman. Awalnya mereka mengikuti kegiatan pembinaan keagamaan hanya karena takut dengan pihak lembaga dan merasa terpaksa, namun lama-kelamaan mereka menjadi terbiasa dan merasa adanya dorongan untuk terus mengikuti pembinaan keagamaan yang diadakan oleh pihak lembaga. Mereka merasakan adanya ketenangan saat mereka mengikuti kegiatan pembinaan keagamaan. Sebagaimana informasi yang di dapatkan dari Bapak Swidianto sebagai berikut: "Dulunya waktu masih awal-awal saya masuk penjara ini saya tidak rutin mengikuti kegiatan-kegiatan keagamaan, bahkan untuk shalat saja saya masih bermalas-malasan. Mungkin karena saya merasa tertekan berada di sini. Setelah lama-kelamaan ya saya mulai terbiasa mengikuti kegiatan ini, dari pribadi saya 
sendiri, saya merasa sangat lebih baik kalau saya mengikuti kegiatan keagamaan. Disinilah saya mampu menenangkan hati saya. Sampai saat ini saya rutin mengikuti semua kegiatan keagamaan" (Wawancara/ 7 Maret 2020).

Informasi yang di dapatkan bahwa pada awal memasuki Lembaga Pemasyarakatan tidak menyukai segala aktifitas yang ada di lembaga pemasyarakatan. Secara perlahan narapidana tersebut mengikuti kegiatan keagamaan yang diadakan di LAPAS. Narapidana menyadari bahwa tidak ada gunanya marah dengan keadaan dan situasi yang dia alami saat ini. Karena semua itu juga atas kesalahan dirinya. Narapidana menemukan ketenangan hatinya saat melakukan shalat, dzikir dan membaca Alquran. Senada dengan apa yang disampaikan oleh ustadz yang memberikan materi pengajian. Saat pertama mengisi pengajian masih banyak dari warga binaan yang acuh terhadap kegiatan keagamaan. Hanya ada sekitar 3 shaf yang mengikuti kegiatan pembinaan. Namun secara perlahan, selalu terlihat wajah baru saat memberikan pengajian terhadap warga binaan. Perlahan-lahan kesadaran tumbuh akan pentingnya ilmu agama dalam kehidupan mereka. Hal ini juga disampaikan oleh Bapak Miswan sebagai berikut: "Setiap kegiatan yang diadakan di lembaga ini harus diikuti oleh warga binaan dengan baik. Mereka terus dihimbau untuk mengikuti kegiatan yang dibuat oleh pihak lembaga. Sifatnya terlihat memaksa, namun ini menjadi peran lembaga pemasyarakatan. Kita bina disini para tahanan dan narapidana agar menjadi manusia yang lebih baik. Kami melihat di awal mereka mengikuti pembinaan memang terlihat berat, apalagi yang baru-baru masuk lapas tapi lamakelamaan mereka terlihat sudah terbiasa dan tidak perlu disuruh lagi untuk mengikuti pengajian atau pengarahan yang diberikan" (Wawancara/ 5 Maret 2020).

Sementara itu, warga binaan Lembaga Pemasyarakatan merasakan bahwa kegiatan pembinaan keagamaan tersebut sangat memberikan pengaruh besar pada dirinya. Meskipun awalnya mereka mengikuti hanya karena rasa takut akan dimarahi pihak LAPAS atau merasa malu kepada warga binaan lainnya, namun setelahnya mereka benar-benar merasakan manfaat dari kegiatan pembinaan tersebut. Sebagaimana informasi dari Bapak Swidianto bahwa: "Awalnya saya mengikuti kegiatan ini atas dasar keterpaksaan, karna adanya himbauan oleh KaLAPAS. Perlahan-lahan saya renungi ternyata membuat saya nyaman. Saya mulai merasa tenang dan menyukai kegiatan keagaamaan yang ada di sini. Saya merasa bahwa saya harus berubah. Saya harus menjadi orang yang lebih baik lagi" Wawancara/ 7 Maret 2020). Mengenai penerimaan warga binaan terhadap kegiatan pembinaan keagaman merupakan suatu hal yang mempengaruhi pencapaian tujuan dari kegiatan pembinaan tersebut. Sementara itu butuh waktu dan tahapan untuk membuat narapidana menjadi terbiasa dan mampu menerima dengan sepenuh hati pembinaan yang diberikan.

\section{Hasil Pembinaan Keagamaan Bagi Narapidana di LAPAS Kelas II B Kualasimpang}

Tujuan pembinaan keagamaan yang dilakukan di Lembaga Pemasyarakatan tidak didapatkan secara instan. Para warga binaan harus melewati waktu yang lama untuk dapat menerima dan mengamalkan apa yang didapatkannya dari pembinaan keagamaan yang diikutinya. Namun berdasarkan data yang didapati dari informan warga binaan Lembaga 
Pemasyarakatan Kelas II B Kualasimpang menunjukkan bahwa dari pembinaan keagamaan yang di ikuti, narapidana mendapatkan hasil yang baik pada dirinya. Informan tersebut mengakui bahwa dirinya merasa lebih tenang dari pada sebelum masuk ke Lembaga Pemasyarakatan. Sebelum masuk ke LAPAS, narapidana merasa dirinya jauh dengan Allah. Sehingga berbuat tindakan yang melanggar hukum dan syariat Agama (Wawancara/ 5 Maret 2020)

Selanjutnya informasi yang didapatkan dari infroman selanjutnya bahwa selama berada di LAPAS dan mengikuti pembinaan keagamaan, narapidana menjadi mahir dalam membaca Alquran. Selama berada di dalam lembaga tersebut narapidana belajar membaca Alquran bersama temannya. Para narapidana merasakan manfaat yang didapatkan dari kegiatan pembinaan keagamaan yang ada di Lembaga Pemasyarakatan. Hal ini sesuai dengan informasi yang didapatkan dari Bapak Miswan: "Alhamdulillah ada beberapa narapidana yang berhasil menjadi bagus setelah mengikuti pengajian. Ada yang sudah mampu mengafal Alquran sembilan juz, ada yang lima atau tiga juz. Itukan merupakan hasil apa yang kita usahakan selama ini. Bukan hanya itu, saya juga melihat bahwa mereka kelamaan juga terbiasa untuk membaca Alquran, shalat Dhuha dan ada juga diantara mereka yang berpuasa senin kamis (Wawancara/ 5 Maret 2020).

Pembinaan Keagamaan telah memberikan pengalaman keagamaan yang membawa para warga binaan ke arah pribadi yang lebih baik. informasi yang didapatkan dari hasil wawancara bersama salah seorang ustadz Sariyadi yang mengisi pengajian di Lembaga Pemasyarakatan dapat dipahami bahwa pada dasarnya manusia diciptakan dengan naluriah yang baik. naluri yang baik itu sering disebut dengan fitrah. Fitrah itulah yang mengarahkan manusia ke jalan tuhannya. Fitrah itu pula yang membuat seseorang dapat mengenali siapa dirinya di hadapan tuhannya. Namun, pengaruh lingkungan yang tidak baik, membuat fitrah manusia menjadi tertutup. Manusia sudah terpengaruh akan menjadi pribadi yang jauh dari fitrahnya. Itulah yang membuat manusia jauh dari jalan tuhannya. Sukar melakukan ibadah, mudah berbuat kerusakan, bermaksiat dan berperilaku yang jauh dari nilai-nilai kebaikan. Jadi, ketika manusia yang memiliki masalah tersebut masuk ke dalam penjara yang kini kita sebut dengan narapidana, ketika belum ada petunjuk yang datang kepada mereka, maka mereka belum mampu menemukan ketenangan hati dan jalan keluar dari masalahnya. Di sinilah perannya dakwah dalam membimbing dan membina mereka agar dapat kembali kepada fitrahnya. Sehingga mereka mampu meredam gejolak nafsu amarah mereka dengan mengubahnya menjadi hal-hal yang positif. Dengan pendekatan agama, kita mampu menyadarkan seseorang untuk dapat memperbaiki diri mereka. Karena syariat Islam itu memuat kebaikan yang menjadikan pemeluknya yang menjalankan syariat tersebut menjadi manusia yang baik dan berakhlak baik (Wawancara/ 08 Maret 2020)

Perilaku religius terlihat jelas pada diri narapidana yang ada dilembaga pemasyarakatan. Mulai dari melakukan shalat sunnah Dhuha, membaca ayat suci Alquran serta bershalawat dan dzikir. Informasi dari Swidianto menyatakan bahwa: "Saya sudah mulai terbiasa shalat lima waktu. Dulu saya sering lalai. Semenjak di LAPAS ini saya juga sudah lebih bagus dalam 
membaca Alquran. Saya merasa lebih dekat dengan agama saya. adanya pembinaan keagamaan di sini memberikan pengaruh yang positif untuk kami. Banyak saya lihat di sini teman-teman saya berubah menjadi lebih baik" (Wawancara/ 7 Maret 2020)

Dari beberapa data hasil wawancara yang telah dibahas menunjukkan bahwa religiositas narapidana di Lembaga Pemasyarakatan Kelas II B Kualasimpang mengalami peningkatan karena adanya pembinaan keagamaan yang diberikan.

\section{PEMBAHASAN}

Bagian pembahasan penelitian berisi diskusi hasil penelitian dan pembandingan dengan teori dan atau penelitian sejenis.

Berdasarkan hasil penelitian bahwa religiositas dapat ditingkatkan dengan pembinaan keagamaan.

\section{Pembinaan Keagamaan dalam meningkatkan religiositas}

Religiositas merupakan bentuk hubungan manusia dengan penciptanya melalui ajaran agama yang sudah terinternalisasi dalam diri seseorang dan tercermin dalam sikap dan perilakunya sehari-hari (Mayasari, 2014). Religiositas mendeskripsikan seberapa baik seseorang mengetahui, memahami ajaran agama Islam, meyakini, dan menghayati ajaran tersebut sehingga terimplementasi dalam perilaku ibadah ritual dan ibadah sosial (Stark \& Glock, 1968; Mastiyah, 2018). Oleh karena itu, perlunya meningkatkan religiositas melaui pembinaan keagamaan.

Pembinaan keagamaan merpakan usaha sadar yang dilakukan secara terarah, demi tercapainya pribadi yang lebih berkompeten dan mempunyai wawasan luas, yang senantiasa berpegang teguh pada nilai-nilai Islam untuk tercapainya keselamatan dunia dan akhirat (Makmun, 2010)

Pembinaan k e agamaan merupakan kegiatan rutin sebagai usaha yang dilakukan secara sadar, terencana, teratur dan bertanggung jawab dalam rangka memberi petunjuk kepada manusia agar dapat selamat dan bahagia hidupnya di dunia maupun di akhirat dengan petunjuk dan arahan wahyu yang diberikan oleh Allah Swt kepada rasul-Nya. Jadi pembinaan keagamaan adalah suatu upaya pengelolaan berupa melatih, membiasakan, memelihara, menjaga dan mengarahkan serta mengembangkan kemampuan seseorang untuk memperoleh hasil yang lebih baik dari sebelumnya.

Tujuan pembinaan keagamaan untuk memperoleh wawasan spiritual, membekali pengetahuan, membimbing cara berpikir, dan mengembangkan relasi dengan melatih membiasakan kebaikan (Mujib \& Mudzakkir, 2006)

Pembinaan keagamaan merupakan hal yang paling urgen keberadaannya terutama di Lembaga Pemasyarakatan. Pembinaan keagamaan diharapkan mampu memberikan perubahan perilaku bagi warga binaan ke arah yang baik. Pada umumnya banyak bentuk kegiatan pembinaan yang dilakukan oleh pihak lembaga pemasyarakatan bagi warga binaan. Pembinaan keagamaan merupakan suatu intervensi yang paling berpengaruh dan yang paling efektif dalam membina para tahanan dan narapidana menuju keadaan perilaku yang lebih baik. Pembinaan keagamaan memiliki potensi yang besar terhadap pembentukan kesadaran bagi narapidana dan tahanan.

2. Implikasi dalam Bimbingan dan Konseling 
Nilai keagamaan telah tertanam dalam jiwa manusia berperan besar dalam perkembangan karakter manusia sehingga religiositas mengajarkan keutamaan yang menjadi cerminan untuk mewujudkan manusia yang jujur dan bertakwa dalam kehidupannya (Safrilsyah dkk, 2010). Religiositas berfungsi mengajar dan membimbing, memberikan jaminan kepada manusia keselamatan di dunia dan akhirat, mengukuhkan yang baik dan menolak kaidah yang buruk, memupuk rasa persaudaraan yang kuat, dan melakukan perubahan terhadap bentuk kehidupan (Fitriani, 2016). Ada beberapa layanan bimbingan dan konseling dalam meningkatkan religiositas seperti layanan informasi dan bimbingan kelompok.

Layanan informasi merupakan kegiatan memberikan pemahaman kepada seseorang tentang berbagai hal yang diperlukan untuk menentukan arah dan tujuan yang diharapkannya (Prayitno, 2004; Marimbun, 2019). Oleh karena itu, perlu memberikan berbagai informasi terkait materi yang berkaitan dengan peningkatan religiusitas.

Layanan Bimbingan Kelompok merupakan salah satu jenis layanan dalam bimbingan dan konseling untuk memperoleh informasi baru terhadap topik yang dibahas (Prayitno, 2004; Marimbun, 2021). Bimbingan kelompok bermanfaat untuk: 1) memberi kesempatan untuk mengemukakan pendapat serta membahas berbagai topik yang terjadi, 2) mendapatkan pemahaman yang okyektif, tepat dan luas dari pembahasan, 3) melahirkan sikap yang positif dengan lingkungan, 4) mempunyai perencanaan kegiatan untuk memberikan dukungan kepada baik dan melakukan penolakan terhadap yang buruk, 5) menjalankan kegiatan yang bermanfaat (Sukardi, 2003; Marimbun, 2021)

\section{SIMPULAN}

Kesimpulan dari hasil penelitian ini adalah sebagai berikut: Pembinaan keagamaan urgen diadakan di Lembaga Pemasyarakatan. Pembinaan keagamaan bekerja sama dengan beberapa lembaga seperti Dinas Syari'at Islam, Mahkamah Syari'ah, Ikatan Da'i Indonesia, Majelis permusyawaratan Ulama, serta pesantren Darul Mukhlisin yang berada di Aceh Tamiang. Hasil kerja sama mengukuhkan pesantren Al- Hikmah di Lembaga Pemasyarakatan Kelas II B Kualasimpang. Keberadaan pesantren Al- Hikmah membantu pembinaan keagamaan berupa shalat berjamaah, dzikir, bershalawat, membaca Alquran, kultum, serta belajar kitab dan mengadakan kajian keagamaan yang diisi oleh berbagai ustadz dari luar Lapas. Respon narapidana terhadap kegiatan pembinaan keagamaan pada awalnya sangat menolak, Namun secara perlahan mereka menyadari manfaat kegiatan tersebut. Pembinaan keagamaan yang dilakukan memberikan efek terhadap peningkatan religiositas warga binaan sehingga menjadikan warga binaan mahir membaca Alquran, mampu menghafal ayat- ayat suci Alquran. Perilaku-perilaku religius narapidana terlihat dari kegiatan narapidana di lembaga pemasyarakatan dengan berbagai kegiatan keagamaan seperti membaca Alquran, shalat sunnah Dhuha, dan sebagainya.

\section{DAFTAR PUSTAKA}

Amin, S. M. (2010). Bimbingan dan konseling Islam. Amzah.

Andriyani, I. N. (2015). Menjaga Kesucian Fitrah Manusia. Al-Manar, 4(2). 
Aziza, A. (2018). Konseling Qur'ani Dalam Bentuk Terapi Fitrah Dengan Menggunakan Teknik-Teknik Reinforcement Positif Untuk Mengatasi Akhlak Buruk Pada Siswa Smk Nw Renco Tahun Ajaran 2017/2018 (Doctoral Dissertation, Universitas Hamzanwadi).

Damayanti, D. (2011). Profesionalisme Petugas Lembaga Pemasyarakatan Dalam Pembinaan Narapidana Di Lembaga Pemasyarakatan Klas Iia Wirogunan Yogyakarta (Doctoral dissertation, UAJY).

DM, I. S. (2017). Jaminan HAM untuk Narapidana dalam Kacamata Sistem Pemasyarakatan di Indonesia. Lex Scientia Law Review, 1(1), 33-40.

Febriani, L. F. (2020). Gambaran Religiusitas Pada Narapidana Di Lembaga Pemasyarakatan Kelas II A Jember (Doctoral dissertation, Universitas Muhammadiyah Jember).

Fitriani, A. (2016). Peran religiusitas dalam meningkatkan psychological well being. Al-Adyan: Jurnal Studi Lintas Agama, 11(1), 57-80.

Gamis, E. J. (2016). Perlindungan Hak-hak Narapidana terhadap Diskriminasi dalam Lembaga Pemasyarakatan. Lex Administratum, 4(3).

Inayah, N. (2020). Pelaksanaan Bimbingan Rohani Dalam Meningkatkan Religiusitas Narapidana Perempuan Di Lembaga Pemasyarakatan Kelas II B Pati (Doctoral dissertation, IAIN KUDUS).

Iryani, E. (2017). Hukum Islam, Demokrasi dan Hak Asasi Manusia. Jurnal Ilmiah Universitas Batanghari Jambi,17(2), 2431.
Islamiyah, S. S. (2020). Pembinaan agama Islam dalam meningkatkan religiusitas narapidana di Pesantren At-Taubah Lembaga Pemasyarakatan Klas I Malang (Doctoral dissertation, Universitas Islam Negeri Maulana Malik Ibrahim).

Jalaludin, R. (2009). Psikologi Komunikasi. bandung: Pt Remaja Rosdakarya.

Juliana, S. (2015). Pelaksanaan Pembinaan Kemandirian Narapidana Di Lembaga Pemasyarakatan Kelas II A Bengkalis Kabupaten Bengkalis. WEDANA: Jurnal Kajian Pemerintahan, Politik dan Birokrasi, 1(1), 25-40.

Makmun, S.A. (2000). Psikologi Kependidikan Perangkat Sistem Pengajaran Modul, Bandung: PT Remaja Rosdakarya

Marimbun, M. (2019). Minat Membaca dan Implementasinya dalam Bimbingan dan Konseling . ENLIGHTEN: Jurnal Bimbingan Konseling Islam, 2(2), 74-84.

Marimbun, M. (2021). Meningkatkan Aspirasi Karier di Sekolah Melalui Layanan Bimbingan dan Konseling. Jurnal Wahana Konseling, 4(1), 1-12.

Marimbun, M. (2021). Meningkatkan Minat Membaca Mahasiswa Melalui Bimbingan Kelompok Topik Tugas. KOPASTA: Journal of the Counseling Guidance Study Program, 8(1), 54-65.

Mastiyah, I. (2018). Religiusitas Siswa Madrasah Aliyah dan Sekolah Menengah Atas. Edukasi, 16(3), 294702.

Mayasari, R. (2014). Religiusitas Islam dan kebahagiaan (Sebuah telaah dengan perspektif psikologi). Al-Munzir, 7(2), 81-100. 
Mujib, A., \& Mudzakkir, J. (2006). Ilmu pendidikan islam.

Mulyani, S. (2018). Bimbingan agama melalui teknik clien centred dalam pembentukan kepribadian remaja: study deskriptif di Yayasan Pendidikan Satu Atap AsSolehhiyah Kelas IX Kec. Bojongsoang (Doctoral dissertation, UIN Sunan Gunung Djati Bandung).

Nisa, A. (2019). Analisis Kenakalan Siswa Dan Implikasinya Terhadap Layanan Bimbingan Konseling. JURNAL EDUKASI: Jurnal Bimbingan Konseling, 4(2), 102-123.

Nurhapidoh, L. (2019). Bimbingan keagamaan untuk menanamkan nilai karakter religius bagi siswa: Penelitian di SD Bintang Madani Cisaranten Bina Harapan, Arcamanik, Kota Bandung (Doctoral dissertation, UIN Sunan Gunung Djati Bandung).

Nurhuda, M. (2020). Perlakuan Khusus Terhadap Narapidana Dalam Perspektif Hukum Pemasyarakatan (Doctoral dissertation, Fakultas Hukum Universitas Pasundan).

Nursakilah, N. (2019). Implementasi Bimbingan Keagamaan Dalam Membangun Sikap Toleransi Beragama Santri Di Tengah Komunitas Tionghoa Di Pondok Pesantren Kauman Kecamatan Lasem Kabupaten Rembang (Doctoral dissertation, IAIN KUDUS).

Prayitno. 2004. Seri layanan konseling. FIP UNP.

Purwasari, J. (2013). Pelaksanaan pendidikan dan pembinaan warga binaan pemasyarakatan wanita di lembaga pemasyarakatan klas ii a samarinda berdasarkan undangundang nomor 12 tahun 1995. Journal of Law (Jurnal Ilmu Hukum), 1(2), 154165.

Rahim, D. H. (2021). Layanan bimbingan konseling seseorang untuk meningkatkan kedisiplinan shalat berjamaah: Penelitian di MA Soebono Mantofani Jombang Ciputat Tanggerang Selatan (Doctoral dissertation, UIN Sunan Gunung Djati Bandung).

Rahmawati, A. (2016). Panduan Pembinaan Sekolah Rumah. Jawa Barat: PP PAUD dan Dikmas.

Ridwan, A. (2018). Peran guru agama dalam bimbingan konseling siswa sekolah dasar. Risâlah, Jurnal Pendidikan dan Studi Islam, 4(1, March), 1-13.

Safrilsyah, S., Baharudin, R., \& Duraseh, N. (2010). Religiusitas Dalam Perspektif Islam: Suatu Kajian Psikologi Agama. Substantia: Jurnal Ilmu-Ilmu Ushuluddin, 12(2), 399-412.

Saryono, S. (2016). Konsep Fitrah dalam Perspektif Islam. Medina-Te: Jurnal Studi Islam, 12(2), 161-174.

Stark, R. \& Glock, C. Y. (1968). American Piety: The Nature of Religious Commitment, Berkeley : University of California Press

Sukardi, D. W. (2003). Pengantar pelaksanaan program bimbingan dan konseling di sekolah. Jakarta: Rineka Cipta.

Sutoyo, A. (2013). Bimbingan dan Konseling Islami (teori dan praktik). Yogyakarta: Pustaka Pelajar.

Whiny Dhiniyati, N. (2019). Pembinaan Narapidana Melalui Pendidikan Keterampilan Pembuatan Sandal Untuk Kemandirian (Studi pada Lembaga Pemasyarakatan Kelas II B Kota 
Pembinaan Keagamaan dalam...- Said Ikhwani, Muhammad Nasir \& Marimbun

Tasikmalaya) (Doctoral dissertation,

Universitas Siliwangi). 